\title{
Transformational Leadership, Organizational Culture and Work Environment Effect on Widyaiswara's Satisfaction and Performance
}

\author{
Maulana Maulana, Mursalim Umar Gani, Achmad Gani, and Muchtar Lamo
}

\begin{abstract}
The purpose of this study is to examine the effects of transformational leadership, organizational culture and work environment on job satisfaction that acts as a mediator and its impact on lecturer's performance which in this study is referred to as Widyaiswara's. The study was conducted in 12 educational and training institutions in South Sulawesi with a population and a sample of 161 Widyaiswara as respondents (census method). Data from the questionnaire analyzed were used to test our hypotheses; we followed the structural equation modeling approach using IBM ${ }^{\circledR}$ SPSS ${ }^{\circledR}$ AMOS $^{T M} 18$. The results found that the transformational leadership has a positive significant on Widyaiswara's satisfaction and performance. We found for indirect effects through Widyaiswara's satisfaction is a positive significant to explain the transformational leadership effect on Widyaiswara performance. The results for positive insignificant indirect effects were found through Widyaiswara's satisfaction on performance, namely work environment variables. The most important effect is proven through transformational leadership in explaining the effect of Widyaiswara's satisfaction and performance.
\end{abstract}

Index Terms-Transformational, culture, work environment, satisfaction, performance

\section{INTRODUCTION}

The key success of an organization in the view of human resource management is largely determined by the share of human resources who play their role in the organization. Human resources are an important part of the success of an organization; therefore human resources are the key to success or failure of an organization in realizing its goals. The lecturer's we called Widyaiswara as a human resource in the organization of educational and training institutions plays an important role in bringing the organization forward and modern. Given the importance of Widyaiswara in an organization is inseparable from the profession it carries. Widyaiswara profession is a profession of educators, instructors and coaches in educational and training institutions which determines the success or failure of the implementation of education and training and meeting

Published on December 5, 2019.

Maulana. M. , Doctoral Program in Indonesian Muslim University Makassar.

Mursalim. U. G. , Economy and Business Faculty in Indonesian Muslim University Makassar.

Achmad. G. , Economy and Business Faculty in Indonesian Muslim University Makassar.

Muchtar, L. , Economy and Business Faculty in Indonesian Muslim University Makassar. the demands of training needs held by government and nongovernment education and training institutions. Competency development program is an essential element in establishing world class civil servants.

Widyaiswara as trainers have strategic roles in improving public service competency. Widyaiswara should develop ideas, breakthroughs, and new innovations on methods and ways of competency developments other than trainings. Previous trainings were fully conducted in a classical or traditional approach that the trainings were delivered within classrooms. However, now the training practices are starting to implement the e-learning method. The credit point scheming of Widyaiswara is no longer stressed on lesson hours. It also considers Widyaiswara's role in developing training materials. With this method, hopefully, we can improve the quality of Widyaiswara. In fact, every change does have risk. However, now we are facing new challenges on how to develop Widyaiswara's functions to be in line with modern learning methods, the government was committed to creating world class civil servants. It could be done by modernizing classical training by implementing the latest technology as well as improving Widyaiswara's recruitment and selection process and development

Widyaiswara's profession is the main profession in the development of human resources in government officials. In accordance with the Regulation of the Minister of Administrative Reform (Permenpan) Number 22 Year 2014 regarding Widyaiswara's Functional position and credit score, that the Widyaiswara are Civil Servants who are appointed as functional officials by authorized officials with duties, responsibilities, authority to educate, teach and training the Civil Servants and serve as facilitators, resource persons, moderators, counselors and discipline enforcers which aim to increase the competency of Civil Servants who receive education and training at Government Training Institutions. Simply put, Widyaiswara has the same obligations as a lecturer in a campus environment and a teacher in a school environment.

The Minister of Administrative Reform regulation Number. 22 of 2014 concerning Widyaiswara's functional position and his credit score that Widyaiswara has 18 competencies that must be carried out by Widyaiswara in carrying out their obligations as apparatus in charge of training and educating Civil Servants. In accordance with Regulation of the Head of the State Administration Agency number 5 of 2008, a Widyaiswara is also required to be more Professional and have a good competency standard. It aims to improve the competence of participants in the Training and Civil Servants so that later the performance of 
Civil Servants can be better in government. In the management of Civil Servants, the development of education and training of Civil Servants is not only related to the development of education and structural training to obtain structural positions, but rather prioritizes the improvement of expertise and skills. This strongly suggests that education and training activities are only a formality that must be carried out by Civil Servants in obtaining structural positions.

Considering the existence of Widyaiswara in educational and training institutions has an important role and is very vital for the development of human resources, so each Widyaiswara is required to improve its performance that has been regulated in the Decree of the Minister of Administrative Reform and the State Administration Agency. Performance demands that each lecturer is able to carry out their duties and functions to produce work in quantity, quality, efficiency, effectiveness and loyalty, in accordance with the implementation of education and training and analysis of training needs.

The phenomenon that has occurred in the past five years shows that the performance of the Widyaiswara has experienced a change in the percentage up and down and tends to not reach the expected target above 95\% well realized, bearing in mind the policies of each educational and training institution vary according to the characteristics educational and training institutions, which have a characteristics bottom up and top down. Educational and training institutions that are characteristic of bottom up accountability to the public and characteristics top down of accountability to the central leadership. The achievement of Widyaiswara's performance is directly influenced by the level of satisfaction of Widyaiswara in carrying out the main tasks and functions of education and training they carry, so there is conformity that the level of job satisfaction has an influence on the achievement of widyaiswara's performance. Usually job satisfaction increases or decreases also affect the Widyaiswara's performance. Determination of targets $>$ $95 \%$ is determined based on the value of widyaiswara job satisfaction stated above criteria above 95 achieve the target and below 95 stated not yet reached the target. It can be seen that the average percentage of job satisfaction has not reached the target set based on the new responsibility indicator of $82.05 \%$, work progress by $86.20 \%$, work achievement $81.94 \%$, recognition by $83.74 \%$ and work itself by $81.69 \%$.

Furthermore, the determination of the target $>95 \%$ is determined based on the performance achievements of widyaiswara stated that the criteria above 95 and above achieved the target and below 95 were stated not to reach the target. It can be seen that the average percentage of performance has not reached the target set based on the quantity indicator of $80.85 \%$, quality of $83.75 \%$, work efficiency $78.66 \%$, work effectiveness $82.19 \%$ and loyalty of $84.92 \%$. The reasons that led to the achievement of Widyaiswara's performance have not reached the expected target, this is inseparable from the achievement of different results from educational and training institutions in realizing their performance achievements, both in quantity, there are still different educational and training institutions in providing assessments according to the number of activities education and training conducted, education and training participants taught or mentored, education and training materials provided, and innovations in the development of education and training provided. In quality, there are differences in the leadership's policy in providing assessments to widyaiswara especially those related to competence, discipline, formal and non-formal education, skills, integrity, leadership, teaching experience / flight hours shown by widyaiswara. Efficiently, the results of work achieved by widyaiswara differ in the use of work time, activity schedules, utilization of priority scale budget and timeliness and budget allocation.

Effectively the performance appraisal achieved by lecturers differs between educational and training institutions according to the evaluation of education and training activities based on the allocation and use of the budget, priorities and elaboration of education and training participants, objectives and targets, and education and training activities according to the scheduled time. Including the assessment of loyalty from widyaiswara's performance that is different from the leadership's assessment of compliance and adherence to the leadership's policies, compliance with applicable rules and attributes and compliance with work procedures and mechanisms. It is a picture of widyaiswara's performance appraisal at educational and training institutions in South Sulawesi as a fact that needs to be considered to be addressed and improved from widyaiswara's performance through the application of individual performance theory explains that the success of an organization in realizing its objectives is assessed from the performance results achieved. Widyaiswara's performance appraisal is measured in terms of quantity, quality, efficiency, effectiveness and loyalty according to organizational demands and leadership policies [1].

The achievement of Widyaiswara's performance has not reached the expected target, directly or indirectly influenced by the level of Widyaiswara's job satisfaction in carrying out its main tasks and functions. There is a growing phenomenon in the Institute of education and training in South Sulawesi with empirical evidence that it is difficult to improve the Widyaiswara performance it is not supported by the fulfillment of job satisfaction. This is relevant to what is stated by scholars, that the achievement of performance is easily realized when job satisfaction is achieved [2].

Achievement of Widyaiswara satisfaction has not reached the target. Decrease in Widyaiswara satisfaction at educational and training institutions in South Sulawesi is affected by Widyaiswara's dissatisfaction in developing educational and training activities. The phenomenon of Widyaiswara satisfaction that has not yet reached the target is reflected in the presence of widyaiswara who are not responsible for carrying out professional duties properly, Widyaiswara's low innovation in teaching progress, lack of achievement in education and training activities, recognition of low credibility in organizing education and training and low attention to the work itself as a profession that must be devoted to wholeheartedly. This symptom is an indication of dissatisfaction experienced by some of the lecturers who affect the performance of the lecturers not achieving the expected target. 
Based on this phenomenon, Widyaiswara's satisfaction needs to be improved and improved in developing responsible satisfaction, realizing progress in organizing education and training, realizing achievement achievements, getting recognition of the credibility of educational and training institutions and enjoying the work of widyaiswara professions. Because it is necessary to apply the theory of hope or two factor theories, that satisfaction is the expression of pleasure and dissatisfaction is the expression of disappointment, these two things are two different factors of hope. There are five aspects of job satisfaction, namely the maintenance of job satisfaction in responsible, to realize development, achievement, recognition and the work it [3].

Widyaiswara's satisfaction and performance that have not reached the target are strongly influenced by transformational leadership, organizational culture and Widyaiswara's work environment. Observing organizational leadership applied to educational and training institutions in South Sulawesi today that is suitable and appropriate to be applied in increasing job satisfaction and Widyaiswara's performance is transformational leadership which is currently disoriented in its application. Currently some leaders of the Institute of Education and Training in South Sulawesi have not been able to actualize the leadership style that is able to motivate Widyaiswara to carry out the demands of their duties. Factual phenomena found in the lack of charismatic, inspired leadership figures, have stimulated individualistic considerations in leading subordinates to realize organizational goals.

There is still a lack of leadership in educational and training institutions that have a leadership style that has behavior that understands the organization's vision and mission, has a strong stand, is consistent with the decisions taken and respects subordinates. The inspiring leader to arousing the optimism and enthusiasm of his subordinates to have great ideas. There is still a lack of leaders who are able to develop intellectual stimulation in leading their subordinates to think carefully, rationally, creatively and innovatively at work, and there is still a lack of leadership capable of developing individual considerations to listen to aspirations, want to educate and train their subordinates to advance in developing organizations.

This lack of transformational leadership ability leads to job satisfaction and Widyaiswara's low performance in disorientation. On this basis, it is necessary to consider implementing transformational leadership as an appropriate style in growing the role and demands of large lecturers in educational and training institutions in South Sulawesi. Widyaiswara needs a transformational leader who has inspiration, intellectual stimulation and individual consideration. This is in accordance with the application of transformational leadership theory proposed by scholars that transformational leadership is a process that motivates followers to carry out roles and task demands in realizing organizational goals according to inspiration, intellectual stimulation and individual considerations [4]. This theory is in line with the contribution of transformational leadership that is applied to realize the roles and demands to increase job satisfaction and Widyaiswara performance in educational and training institutions in South Sulawesi. In addition to transformational leadership, organizational culture directly also influences job satisfaction and Widyaiswara's performance has not reached the target. The fact is based on factual phenomena found that there are some lecturers who do not understand the existence of organizational culture in educational and training institutions in South Sulawesi, especially for Widyaiswara who still do not have experience understanding the basic philosophies of the founding fathers of previous organizations which have laid the foundations of values, norms and principles organizational culture. Due to lack of a strong organizational culture, job satisfaction and Widyaiswara's performance have not reached the target. This is the cause of the lack of actualization of organizational culture, due to the low understanding of the value of integrity, identity, reliability, work ethics and goal orientation that have not been well embedded as an important part of the culture that must be actualized by all members of the organization. As a result of this low organizational culture has an influence on job satisfaction and Widyaiswara performance.

Given the importance of strengthening organizational culture as a basic philosophy that has become a habit that has been inherited by the founders of the organization, it is necessary to embody organizational culture for each lecturer at the Institute of education and training in South Sulawesi to have integrity values to be people who have honesty in carrying out their duties and organizational demands, must be able to develop the value of self-identity as the pride of the organization, show reliability in developing tasks assigned by the organization, always have a high work ethic for organizational progress, and be able to develop the expected organizational orientation by multiplying local wisdom. This is consistent with the theory of cultural philosophy that organizational culture is a philosophy of local wisdom that is embedded and embraced by every member of the organization in realizing its goals. According to the practice of the value of integrity, identity, reliability, work ethics and orientation of the purpose of its existence in local wisdom [5].

Equally important that affects job satisfaction and Widyaiswara's performance has not reached the target is the influence of the work environment of Widyaiswara itself. Every Widyaiswara in carrying out her work activities requires a conducive environment in accordance with her needs and interests. Widyaiswara needs a work environment with a pleasant working atmosphere, harmonious working relations, available work facilities, light / air circulation and workplace security, which directly or indirectly influences job satisfaction and Widyaiswara's performance. In fact Widyaiswara from several educational and training institutions in South Sulawesi have differences in viewing the work environment they face. Not all Widyaiswara feel a pleasant working atmosphere due to noisy, crowded and irregular workplaces, especially the classrooms where the education and training are held. Including work environment that is not supportive of relationships between coworkers who are not harmonious, such as interpersonal conflict, unpleasant behavior between fellow colleagues and a broken emotional relationship.

The usual work environment that influences job satisfaction and Widyaiswara's performance can also be seen 
from the work facilities of each training education institution that is not available and many are damaged, so it does not support the process of implementing education and training. Including the work environment that is often complained by Widyaiswara is the aspect of lighting or lighting as well as class air circulation which is often complained of. It also includes the security aspects of the work environment of each of the different educational and training institutions, especially the security of the dormitory, study rooms, parking spaces that are not guarded by security officers which cause frequent theft or loss of goods. This consideration of the importance of the work environment is supported by a conducive work theory that a conducive work environment determines job satisfaction and individual performance in the organization. The better the work environment, the more fulfilled someone's satisfaction to work in improving their performance. The manifestation of a conducive work environment is a working atmosphere, working relationships, work facilities, lighting / air circulation and security which must be realized and provided by the organization [6].

\section{LITERATURE REVIEW AND HYPOTHESIS TESTING}

\section{A. Transformational Leadership}

Submit your manuscript electronically for review.

The leaders are individuals who can provide vision and mission, instill pride, gain respect and trust. Inspired leaders carry out their activities by communicating high expectations, using symbols to focus efforts, expressing important intentions in a simple way. Leaders with intellectual stimulation always promote intelligence, rationality and problem solving studied. The leadership of individual consideration by giving personal attention, treating each employee individually, training (coach), advising. Transformational leadership has indicators, inspiration, intellectual stimulation and individual consideration [3].

$\mathrm{H}_{1}$ : Transformational leadership has positive significant effect on widyaiswara's satisfaction

$\mathrm{H}_{2}$ : Transformational leadership has positive significant effect on widyaiswara's performance.

\section{B. Organizational Culture}

Organizational culture is an added value when the elements of integrity, identity, reliability, work ethics and results orientation become an inseparable chain. The implications of organizational culture cannot be separated from aspects of the founders' philosophies, values, work ethics, principles and rules that make the culture a model of group culture, rational and adocracy [7]. Organizational culture produces a core value in seeing the concept of organizational culture as a way of looking at achieving goals. These core values include integrity, identity, reliability, work ethics and results orientation to realize organizational goals [8].

$\mathrm{H}_{3}$ : Organizational culture has a positive significant effect on Widyaiswara's satisfaction

$\mathrm{H}_{4}$ : Organizational culture has a positive significant effect on Widyaiswara's performance

\section{Work Environment}

The work environment is a very important component when workers carry out work activities. By paying attention to a good work environment or creating working conditions that can provide motivation to work, it will bring an influence on the performance of workers at work [9]. The work environment is explained as the overall tools and materials faced by the surrounding environment in which a person works, his work methods, and work arrangements both as individuals and as a group [10]. The condition of the work environment is said to be good or appropriate if humans can carry out activities optimally, healthy, safe and comfortable [5].

$\mathrm{H}_{5}$ : Work environment has a positive significant effect on Widyaiswara's satisfaction

$\mathrm{H}_{6}$ : Work environment has a positive significant effect on Widyaiswara's performance.

\section{Widyaiswara's Satisfaction}

Widyaiswara's satisfaction is basically something that is universal. Each individual has a different level of satisfaction in accordance with the assessment of feelings. The more fulfilled what is felt or expected, the more actualization of satisfaction is fulfilled. Job satisfaction theory in this study refers to maintenance theory, that one's satisfaction is determined by the maintenance factor in the form of satisfaction and dissatisfaction, which is interpreted in the form of; (1) responsibility, the size of the perceived and given to the workforce; (2) progress, the size of the possibility of labor can advance in their work; (3) achievement(achievement), the size of the labor force achieve high performance; (4) recognition (recognition), the size of the recognition given to workers for their performance; and (5) work itself, the size of the challenges for the workforce from work [11].

$\mathrm{H}_{7}$ : Widyaiswara's satisfaction has a positive significant effect on Widyaiswara's performance

\section{E. Widyaiswara's Performance}

Widyaiswara's performance is the achievement of results that have added value. The added value in question is the work that is measured in quantity, quality, efficient and effective. While those related to behavior can be categorized according to the level of loyalty in contributing to the increase in added value [12]. A person's performance can be seen from the achievement of more and more profitable work. That is, the more the amount of work produced, the greater the benefits or benefits derived from the work produced or in other words a person's performance can be assessed from the achievement of work results in quantity $[6,13,14,15]$.

$\mathrm{H}_{8}$ : Widyaiswara's is a mediator between transformational leadership and Widyaiswara's performance

$\mathrm{H}_{9}$ : Widyaiswara's satisfaction is a mediator between organizational culture and Widyaiswara's performance

$\mathrm{H}_{10}$ : Widyaiswara's satisfaction is a mediator between work environment and Widyaiswara's performance 


\section{METHODS}

This research is designed to answer the problems that have been formulated and the objectives to be achieved and test the hypothesis. The location of the study was conducted by the Education and Training Institute in South Sulawesi as an object of research to see the effect of transformational leadership, organizational culture and work environment on job satisfaction and widyaiswara performance. Research time is scheduled for three months from May to June 2019. There are two types of research, namely quantitative and qualitative research. Sources of data in this study consisted of primary and secondary data. Data collection techniques (instruments) used were observation, questionnaire, interview and documentation. The population and sample in this study were all lecturers who worked at 12 (twelve) training education venues in Makassar City, South Sulawesi Province with a total of 161 people (census method). Data analysis techniques used in explaining the phenomena in this study are descriptive statistical analysis techniques and to test our hypotheses, we followed structural equation modeling approach using IBM $®$ SPSS ${ }^{\circledR}$ AMOS $^{\mathrm{TM}} 18$.

\section{ANALYSIS AND DiSCUSSION}

The test variables of this first model are grouped into exogenous variables and endogenous variable. Exogenous variables are variables whose values are determined outside the model. Whereas endogenous variables are variables whose value is determined through equations or from established relationship models. Included in exogenous variable groups are measurements of transformational leadership, organizational culture and work environment, while those classified as endogenous variables are job satisfaction and performance. The model is said to be good when the development of a hypothetical model is theoretically supported by empirical data. The complete confirmatory factor analysis results can be seen in following the figure:

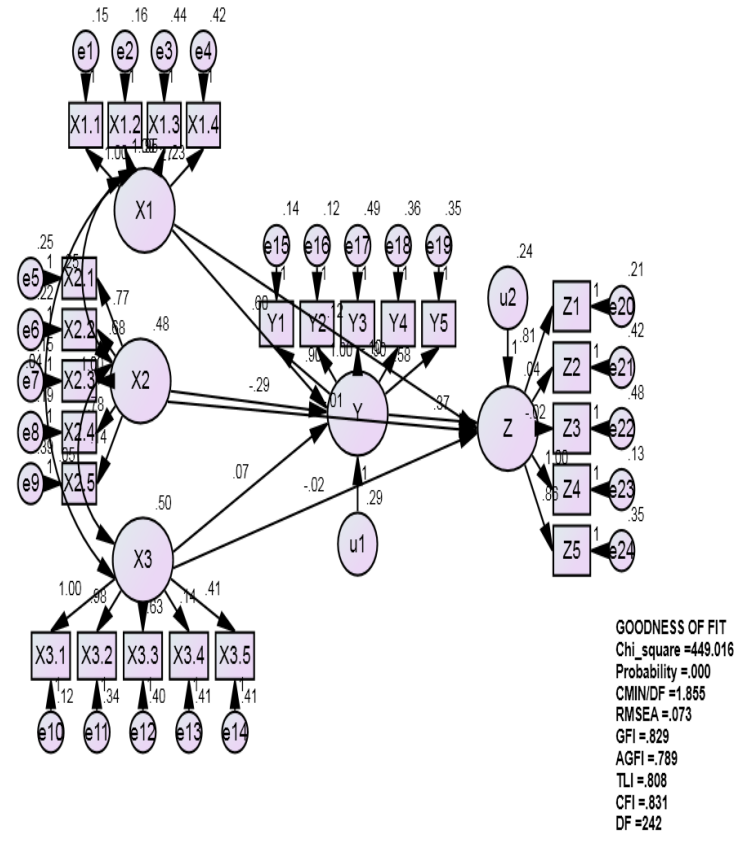

Fig. 1. Measurement of variable relationship model (1)
The evaluation of the model shows that of the eight criteria for goodness of fit indices, the chi-square value is still large and it seems that some criteria do not match the value cut-off specified, so that the model is modified by correlating between indicator errors in accordance with the instructions of the modification indices. The analysis results after the final model obtained are as follows:

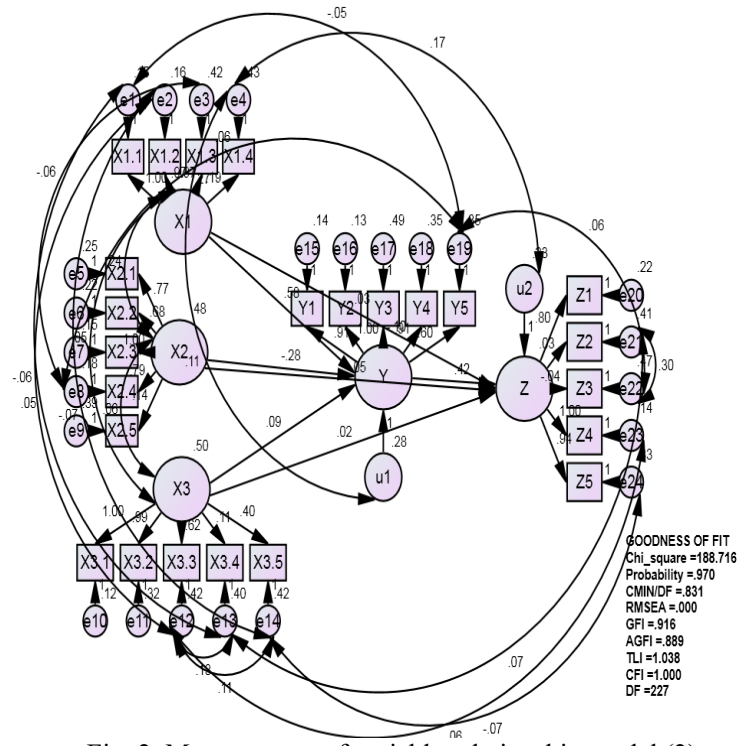

Fig. 2. Measurement of variable relationship model (2)

The model test results presented in Figure 2 are evaluated based on the goodness of fit indices in Table 1 with the model criteria and critical values that have data suitability presented.

TABLE I: GOODNESS OF FIT INDICES OVERALL

\begin{tabular}{lccccc}
\hline CMIN/DF & RMSEA & GFI & AGFI & TLI & CFI \\
\hline $1.855(1)$ & $0.073(1)$ & $0.829(1)$ & $0.789(1)$ & $0.808(1)$ & $0.831(1)$ \\
\hline $0.831(2)$ & $0.000(2)$ & $0.916(2)$ & $0.889(2)$ & $1.038(2)$ & $1.000(2)$ \\
\hline & & Model (1) & Model (1) \\
Chi_Square & & 449.016 & 0.000 \\
Probability & & 188.716 & 0.970 \\
\hline
\end{tabular}

The results of the evaluation model for early stage shows of the eight criteria of goodness of fit indices there were two has fulfilled thecriteria cut-off value, starting from CMIN / DF and RMSEA, so it is necessary to modify the model according to the instructions from the modification indices. Modification Indices (MI) is a calculation to make changes to numbers, where the numbers below indicate the minimum value of the chi-square that will go down if the corresponding variables are connected. After modification of the model, the final stage shows that the eight criteria for goodness of fit indices meet the criteria or cut-off values, so the model is said to be in accordance with the criteria for goodness of fit indices for analysis.

Based on the empirical model proposed in this study, testing of hypotheses can be tested through path coefficient testing on structural equation models. Table 2 is testing the hypothesis by looking at the $p$-value, if the $p$ value is less than 0.05 then the relationship between variables is significant. It also explains the direct effect, means that there is a positive influence directly between variables, the indirect effect, means that there is a positive influence indirectly between the variables, and the total effect, that is the accumulation of direct effects and indirectly. The test 
results are presented in the following table:

TABLE II: HYPOTHESIS TESTING

\begin{tabular}{|c|c|c|c|c|}
\hline Hypothesis & \multicolumn{2}{|l|}{ Causality effect } & $\begin{array}{l}\text { Total } \\
\text { effect }\end{array}$ & $\begin{array}{c}\text { p- } \\
\text { value }\end{array}$ \\
\hline \multirow[t]{2}{*}{$\mathrm{H}_{1}$} & \multicolumn{2}{|l|}{ Transformational } & 0.591 & 0.000 \\
\hline & $\begin{array}{l}\text { leadership } \\
\text { satisfaction }\end{array}$ & Job & & \\
\hline \multirow[t]{2}{*}{$\mathrm{H}_{2}$} & $\begin{array}{l}\text { Transformational } \\
\text { leadership }\end{array}$ & \multirow[t]{2}{*}{$\rightarrow$} & \multirow[t]{2}{*}{0.395} & \multirow[t]{2}{*}{0.000} \\
\hline & $\begin{array}{l}\text { Widyaiswara's } \\
\text { performance }\end{array}$ & & & \\
\hline $\mathrm{H}_{3}$ & $\begin{array}{l}\text { Organizational culture } \\
\text { Job satisfaction }\end{array}$ & $\rightarrow$ & 0.445 & 0.028 \\
\hline $\mathrm{H}_{4}$ & $\begin{array}{l}\text { Organizational culture } \\
\text { Widyaiswara's } \\
\text { performance }\end{array}$ & $\rightarrow$ & 0.314 & 0.011 \\
\hline $\mathrm{H}_{5}$ & $\begin{array}{l}\text { work environment } \rightarrow \\
\text { satisfaction }\end{array}$ & Job & 0.262 & 0.014 \\
\hline \multirow[t]{2}{*}{$\mathrm{H}_{6}$} & \multicolumn{2}{|c|}{ environment $\rightarrow$} & \multirow[t]{2}{*}{0.295} & \multirow[t]{2}{*}{0.033} \\
\hline & $\begin{array}{l}\text { Widyaiswara's } \\
\text { performance }\end{array}$ & & & \\
\hline \multirow[t]{2}{*}{$\mathrm{H}_{7}$} & Job satisfaction & \multirow[t]{2}{*}{$\rightarrow$} & \multirow[t]{2}{*}{0.569} & \multirow[t]{2}{*}{0.000} \\
\hline & $\begin{array}{l}\text { Widyaiswara's } \\
\text { performance }\end{array}$ & & & \\
\hline \multirow{2}{*}{$\begin{array}{c}\mathrm{H}_{8} \\
\text { Sobel test }\end{array}$} & Transformational & \multirow[b]{2}{*}{$\begin{array}{c}\text { Job } \\
\rightarrow\end{array}$} & \multirow[t]{2}{*}{0.580} & \multirow[t]{2}{*}{0.000} \\
\hline & $\begin{array}{l}\text { leadership } \quad \rightarrow \\
\text { satisfaction } \\
\text { Widyaiswara's } \\
\text { performance }\end{array}$ & & & \\
\hline \multirow{3}{*}{$\begin{array}{c}\mathrm{H}_{9} \\
\text { Sobel test }\end{array}$} & Organizational culture & $\rightarrow$ & \multirow[t]{3}{*}{0.492} & \multirow[t]{3}{*}{0.005} \\
\hline & Job satisfaction & $\rightarrow$ & & \\
\hline & $\begin{array}{l}\text { Widyaiswara's } \\
\text { performance }\end{array}$ & & & \\
\hline \multirow{3}{*}{$\begin{array}{c}\mathrm{H}_{10} \\
\text { Sobel test }\end{array}$} & work environment $\rightarrow$ & Job & \multirow[t]{3}{*}{0.464} & \multirow[t]{3}{*}{0.132} \\
\hline & satisfaction & $\rightarrow$ & & \\
\hline & $\begin{array}{l}\text { Widyaiswara's } \\
\text { performance }\end{array}$ & & & \\
\hline
\end{tabular}

The p-value results on the indirect effect of independent variables through intermediate variables on the dependent variable in SEM analysis showed a positive and significant effect, then to prove the indirect effect, Sobel test (Sobel Test of Mediation for Baron \& Kenny Approach) [16] with the following the figure calculation results:

\section{Results}

Indirect Effect $(a \cdot b)=0.364$

Sobel's SE $=\sqrt{ }\left[(a \cdot \mathrm{SE} b)^{2}+(b \cdot \mathrm{SE} a)^{2}\right]=0.105$ $Z=$ Indirect Effect $\div$ Sobel's SE $=3.483$

$p=0.000$

Standardized Indirect Effect $=\left(\beta_{a} \cdot \beta_{b}\right)=0.268$ Portion of $(\mathrm{X} \rightarrow \mathrm{Y})$ due to $\mathrm{M}=\left(c-c^{\prime}\right) / c=100.0 \%$

Fig. 3. Transformational leadership $\rightarrow$ Job satisfaction $\rightarrow$ Widyaiswara's performance

Transformational leadership indirectly through job satisfaction has a positive significant effect on performance with the results of the Sobel standardized indirect effect test of 0.268 with $\mathrm{p}$-value $=0.000<0.05$.
Results

Indirect Effect $(a \cdot b)=0.229$

Sobel's SE $=\sqrt{ }\left[(a \cdot \mathrm{SE} b)^{2}+(b \cdot \mathrm{SE} a)^{2}\right]=0.081$

$Z=$ Indirect Effect + Sobel's SE $=2.811$

$p=0.005$

\begin{tabular}{rr} 
Standardized Indirect Effect $=\left(\boldsymbol{\beta}_{a} \cdot \boldsymbol{\beta}_{b}\right)=$ & 0.206 \\
Portion of $(\mathrm{X} \rightarrow \mathrm{Y})$ due to $\mathrm{M}=\left(c-c^{\prime}\right) / c=$ & $100.0 \%$ \\
\hline
\end{tabular}

Fig. 4. Organizational culture $\rightarrow$ Job satisfaction $\rightarrow$ Widyaiswara's performance

Organizational culture indirectly through job satisfaction has a positive and significant effect on performance with Sobel standardized indirect effect test results of 0.206 with p-value $=0.005<0.05$

\begin{tabular}{|c|c|}
\hline \multicolumn{2}{|l|}{ Results } \\
\hline Indirect Effect $(a \cdot b)=$ & 0.153 \\
\hline Sobel's SE $=\sqrt{ }\left[(a \cdot \mathrm{SE} b)^{2}+(b \cdot \mathrm{SE} a)^{2}\right]=$ & 0.102 \\
\hline$Z=$ Indirect Effect + Sobel's $\mathrm{SE}=$ & 1.507 \\
\hline$p=$ & 0.132 \\
\hline Standardized Indirect Effect $=\left(\beta_{a} \cdot \beta_{b}\right)=$ & 0.119 \\
\hline Portion of $(\mathrm{X} \rightarrow \mathrm{Y})$ due to $\mathrm{M}=\left(c-c^{\prime}\right) / c=$ & $100.0 \%$ \\
\hline
\end{tabular}

Fig. 5. Work environment $\rightarrow$ Job satisfaction $\rightarrow$ Widyaiswara's performance

The work environment indirectly through job satisfaction has a positive and not significant effect on performance with the results of the Sobel Standardized Indirect Effect test of 0.119 with $p$-value $=0.132>0.05$.

The overall model of the seven direct paths and the three indirect pathways were hypothesized, based on the results of the SEM-AMOS analysis giving a positive and significant effect. While Sobel test analysis results for the indirect effect of showing the work environment $\left(X_{3}\right)$ through job satisfaction and no significant positive effect on performance.

The interpretations of Table 2 can be explained as, transformational leadership has a direct positive and significant influence on job satisfaction with $\mathrm{p}=0.000$ $<0.05$ and the coefficient value of 0.591 , this coefficient indicates that the application of transformational leadership is appropriate and gives job satisfaction to each lecturer. Organizational culture has a positive and significant direct effect on job satisfaction with $\mathrm{p}=0.023<0.05$ and coefficient values of 0.455 , this coefficient indicates that organizational culture is good and gives job satisfaction to every lecturer. Work environment has a positive and significant direct effect on job satisfaction with $\mathrm{p}=0.014$ $<0.05$ and coefficient values of 0.262 , this coefficient indicates that a comfortable work environment has been realized and provides job satisfaction to each lecturer.

Transformational leadership has a positive and significant direct effect on job satisfaction with $\mathrm{p}=0.000<0.05$ and coefficient value of 0.395 , this coefficient indicates that the 
application of transformational leadership determines the improvement of widyaiswara's performance. Organizational culture has a positive and significant direct effect on job satisfaction with $\mathrm{p}=0.011<0.05$ and coefficient values of 0.314 , this coefficient indicates that the application of organizational culture determines the improvement of widyaiswara's performance. Work environment has a positive and significant direct effect on job satisfaction with $p=0.033<0.05$ and coefficient values of 0.295 , this coefficient indicates that a conducive work environment determines the improvement of widyaiswara's performance. Job satisfaction has a positive and significant direct effect on widyaiswara's performance with $\mathrm{p}=0.000<0.05$ and coefficient of 0.569 , this coefficient indicates that the achievement of job satisfaction affects the increase in widyaiswara's performance.

Transformational leadership through job satisfaction has a positive and significant indirect effect on performance with coefficient values analysis results indirect effect of 0.185 . While the results of calculations through the sobel test obtained by 0.268 with a significance level of $p$ that is 0.000 $<0.05$ (significant), proving that the transformational leadership shown widyaiswara has provided job satisfaction, and indirectly had a significant effect on improving performance. Organizational culture through job satisfaction has a positive and significant indirect effect on performance with coefficient values analysis results indirect effect of 0.178 . While the results of calculations through the sobel test were obtained at 0.206 with a significance level of $p$, namely $0.005<0.05$ (significant), proving that the organizational culture applied by Widyaiswara had provided job satisfaction, and indirectly had a significant effect on performance improvement.

Work environment through job satisfaction has a positive and significant indirect effect on performance with coefficient values the results ofanalysis indirect effect of 0.169 . While the results of calculations through the sobel test obtained by 0.119 with a significance level of $p$ that is $0.132>0.05$ (insignificant), proving that the work environment still needs to be addressed to provide job satisfaction to widyaiswara, and indirectly will improve its performance.

Analysis of influence the direct effect, indirect effect and the total effect between variables in the model, was used to compare the effect of each variable constructs. The direct effect is the coefficient of all coefficient lines with one end of the arrow, while the indirect effect is the effect that appears through an intervening variable while the total effect is the influence of various relationships [16]. The results of the influence test presented in the table show the magnitude of direct, indirect and total influence between variables.

\section{CONCLUSION}

Based on the analysis of the results and discussion of the study, it is concluded as Transformational leadership plays an important role in influencing job satisfaction. This is evident the results of the study show that transformational leadership has a positive and significant effect on widyaiswara job satisfaction. Organizational culture becomes a fundamental philosophy in influencing job satisfaction. This is proven by the results of research showing that organizational culture has a positive and significant effect on widyaiswara job satisfaction.

A conducive work environment is needed in influencing job satisfaction. This is evident the results of the study indicate the work environment has a positive and significant effect on widyaiswara job satisfaction. Work-oriented transformational leadership influences performance improvement. This is evident the results of the study indicate that transformational leadership has a positive and significant effect on widyaiswara's performance.

Organizational culture that is loaded with values and work principles influences performance improvement. This is proven by the results of research showing that organizational culture has a positive and significant effect on widyaiswara's performance. Work environment that is integrated with work dynamics influences performance improvement. This is evident the results of the study indicate the work environment has a positive and significant effect on widyaiswara's performance. Job satisfaction that is fulfilled affects the performance improvement. This is evident the results of the study show job satisfaction has a positive and significant effect on widyaiswara's performance.

Transformational leadership through fulfilling changeoriented job satisfaction gives an influence on performance improvement $[17.18,19]$. This is evident the results of the study indicate that transformational leadership indirectly through job satisfaction has a positive and significant effect on widyaiswara's performance. Organizational culture through job satisfaction that is embedded in individuals gives an influence on improving performance [20,21,22]. This is proven by the results of research showing that organizational culture indirectly through job satisfaction has a positive and significant effect on widyaiswara's performance and work environment through the fulfillment of job satisfaction does not contribute in influencing performance improvement. This is evident the results of the study indicate the work environment indirectly through job satisfaction has a positive and not significant effect on widyaiswara's performance.

\section{REFERENCES}

[1] Schemerhorn, French, Hunt, Briant, \& Osborn. (2007). Human Resource in Performance Management. $2^{\text {nd }}$ Edition, Mas Hougton Mifflin Company, Boston.

[2] Rivai, Veithzal \& Sedarmayanti. (2008). Human Resources Management. Publisher Rajawali Press, Jakarta

[3] Rivai, Veithzal. (2013). Performance Appraisal. Publisher Rajawali Press, Jakarta

[4] Luthans, Fred. (2007). Organizational Culture. New York, McGrawHill Book Company, $3^{\text {rd }}$, edt. International journal of public administration, 27 (13-14), 1101-1127.

[5] Sedarmayanti. (2008). Organizational Management. Rineka Cipta Publisher, Jakarta.

[6] Toban, C., \& Sjahruddin, H. (2016). The antecedent and consequence of Organizational Commitment and Job Satisfaction.Journal of Business and Management Sciences,4(2), 26-33.

[7] Stolovitch, Storryl, \& Keeps, Storey. (2007). Managing Resource and Performance. Buckingham: Open University Press.

[8] Gibson, James L., Ivancevich, John M. \& Donnely, James. (2004). Organizational Behavior, Structure, Process. Journal of International Studies, Vol. 8 No. 1, pp. 81-90,

[9] Cleveland, Musk, (2008). Performance. Published by Harper T \& Row, New York. 
[10] Idris, M. H., Mappamiring, \& Sjahruddin, H. (2019). Contributing values of organizational justice and competence in increasing trust in leaders. National Seminar on Indonesian Management Forum 11. Samarinda 84

[11] Dessler, Gary. (2007). The Good of Culture Organization in Company. Published by Addison-Wesley Publishing Company.

[12] Bernadin, H. J. and Russel, J. E. (2012). Organization Management and Performance. Journal of International Human Resource Management. Elsevier. doi: 10.1016 / j.jimonfin.2004.01.002.

[13] Nelson, Neil. (2007). Human Resource Management in Strength Quality Prospective. Journal of business research, 60 (3), 277-284 ..

[14] Hasanuddin, R., \& Sjahruddin, H. (2017). The structure of emotional intelligence, spiritual intelligence and its relationship with work enthusiasm and auditor performance.Structure,3(1).

[15] Ferdinand, Augusty. (2011). Structural Equation Modeling in Management Research. FE Diponegoro University, Semarang.

[16] Dekker, Mascule. (2007). Satisfaction and Application in Globalization Era. http://www.journalmotivation.com.id.

[17] Furtwengler, Dale. (2007). Attitudes Performance Organization. Englewood Cliffs, Prentice Hall, New Jersey.

[18] Anshory, Rahmadan. (2004). Human Resource Development in a Conducive Work Environment. Publisher Raja Grafindo Persada, Jakarta.

[19] Beer, M. \& Spector, B. (2010). Human Resource Management. Published by McGraw Hill, Ohio.

[20] Chung \& Ruben. (2007). Application of Human Resources in Organizations. John Wiley and Sons Procedia - Social and Behavioral Sciences, Vol 62, p. 489-493.

[21] Filert, Hans. (2013). Appraising of Performance: Application Theory. Journal of Performance and HRM. Vol. 8 Issue 4, pp. 46-60, ISSN 1804-1728. DOI: 10.7441 / joc.2016.04.03.।

[22] Sjahruddin, H., \& Sudiro, A. A. (2013). Organizational justice, organizational commitment and trust in manager as predictor of organizational citizenship behavior. Interdiciplinary $J . \quad$ of contemporary Res. Bus.(IJCRB), 4(12), 133-141. 